\title{
Review Article \\ Research of Microcosmic Affection Factors on Capital Misallocation: A Case of Chinese Listed Companies
}

\author{
Zhefan Piao, ${ }^{1,2}$ Jini Jia, ${ }^{1}$ Fangyan Shen, ${ }^{1}$ and Rongda Chen ${ }^{1,2}$ \\ ${ }^{1}$ School of Finance, Zhejiang University of Finance \& Economics, Hangzhou 310018, China \\ ${ }^{2}$ China Academy of Financial Research (CAFR), Zhejiang University of Finance \& Economics, Hangzhou 310018, China \\ Correspondence should be addressed to Rongda Chen; rongdachen@163.com
}

Received 15 April 2016; Accepted 19 July 2016

Academic Editor: Xiaodong Lin

Copyright (c) 2016 Zhefan Piao et al. This is an open access article distributed under the Creative Commons Attribution License, which permits unrestricted use, distribution, and reproduction in any medium, provided the original work is properly cited.

\begin{abstract}
With the restrictions of equity financing of Chinese listed companies, debt dimensions are increasing, and the issue of corporate financial structure and financing constraints influence on capital misallocation has become an important practical problem which Chinese listed companies face. This paper is concerned with a model about capital misallocation and its influencing factors of integrated financing, capital operation, and investment performance. We take 7096 observations of 646 Chinese listed companies during fiscal years 2003 to 2014 for A-shares on the Shanghai and Shenzhen stock exchange, for instance, to empirically test the microscopic influencing factors of capital misallocation under different external financing dependence. The study illustrates the following: (1) in descriptive statistics of different industries capital misallocation, more than half of firms experience the circumstance of capital misallocation; (2) although Chinese listed companies are faced with financing constraints, capital market inefficiency, and other issues, most companies still depend on external financing; (3) the main factors that affect capital misallocation of the listed companies are financial liquidity and financial pledgeability; (4) the firms with high innovation abilities generally have stronger profitability, superior financial liquidity, and better financial pledgeability, thus reducing corporate capital misallocation; (5) the Chinese listed companies with large-scale assets and strong profitability easily obtain bank loans and equity financing, while violating the principle of assets matching.
\end{abstract}

\section{Introduction}

Chinese capital market has assumed proportions of a minor industry, but there are still structural defects because of economic characteristics existing in the transition, for example, lack of effectiveness in the stock market, the deformed development of corporation bonds market, excessive policy intervention, and credit discrimination in bank loans. As a result, Chinese listed companies often face financial constraints, and the microcosmic factors of capital misallocation are much complicated $[1,2]$. Significantly, after the financial crisis in 2008, with the restrictions of equity financing of Chinese listed companies (the principal means for refinancing of listed companies is issuance and allotment), debt dimensions are increasing. In 2004 the disclosure of listed companies' financial statements shows that more than 560 companies' debts accumulated up to about 3 trillion yuan. From 2014 to the end of April in 2015, over 100 listed companies still had the default fund scale up to 1226 billion yuan. It is worrying that the proportion of short-term debt in debt maturity structure of Chinese listed companies is too large, resulting in serious and severe financial risk contrary to the principle of time matching. Some empirical researches have shown the microcosmic factors of Chinese listed companies influence the capital misallocation, but under the financing constraints, it is controversial to the effect and degree of these factors. Some problems should be further studied by theoretical analysis and empirical test. Particularly, what is the extent of capital misallocation of Chinese listed companies which are vulnerable to external financial environment? What are the microcosmic factors of capital misallocation?

In that context, conducting on the degree of capital misallocation of Chinese listed companies, this paper develops a model for measuring capital misallocation by referencing the 
study of Hsieh and Klenow, Sordi et al., and Uras [2, 3]. Using listed companies panel date (2001-2014), this model introduces financing constraints, financial pledgeability, financial structure, invested capital, capital misallocation, loss ratio, and other variables to empirically study the microcosmic factors of capital misallocation. In line with the empirical results, this paper raises some specific suggestions to improve capital allocation efficiency.

\section{Literature Review}

Capital market imperfections will lead to capital flow barriers, capital congestion, and scarcity between regions or industries, the allocation of capital in the absence of equalizing marginal revenue products of capital across plants, and thus capital misallocation $[3,4]$. The capital misallocation includes internal and external capital market misallocation $[5,6]$.

In recent years, the studies of phenomenon and factors about capital misallocation in Chinese listed companies have made a breakthrough. Song et al. and $\mathrm{Li}$ et al. suggested that state-owned enterprises have easier access to capital than non-state-owned enterprises, while the investment performance is opposite. The fact that the resource is controlled by government in China leads to capital misallocation [7, 8]. Chen and $\mathrm{Hu}$ illustrated that resources misallocation among Chinese internal manufacturing industry approximately causes a 15 percent gap between actual and potential output [9]. Mao and Gai et al. found that the misallocation in factor markets impedes the improvement of internal enterprise productivity and the cross-enterprise allocative efficiency of resources $[10,11]$. Zhan et al. testified that the distortion of credit rationing results in the variation of investment behavior from the listed companies [12]. Wang and Yuan studied that the monopoly of the financial system suppresses the free flow of capital and results in a greater degree of misallocation among interindustrial capital and then leads to a decline in resource allocation efficiency [13]. These studies mainly focus on the macrofactors of the effects on firms' capital misallocation.

There are still some disputes about the microcosmic factors influencing the capital misallocation in listed companies from China. The first is a problem about the impact of financial structure on capital misallocation. Domestic scholars generally believe that the differences about corporate financing constraints, capital adjustment cost and unreasonable debt term structure, corporate governance mismatches with investment, and financing maturity are the main reasons $[4,5,14,15]$. But foreign scholars consider that the liquidity of corporate finance and financial pledgeability are the main causes of the capital misallocation [2]. The second is a problem about the impact of financing constraints on the investment efficiency of cash holdings from listed companies. Cash holdings marginal value of financial constraints firms is significantly higher than that of nonfinancial constraints firms. Invest in the project whose NPV is positive and avoid lack of investment so as to promote the value of the company $[16,17]$. But there are also many scholars who suggested that, in different nature of firm and industry, the investment efficiency of cash holdings in financial constrained firms is significantly higher than that in nonfinancial constrained firms; besides, financial constrained firms have lower capital misallocation [7, 8, 18]. However, the measure of financing constraints is highly contested. Most are based on $\mathrm{KZ}$ learning from the method of $\mathrm{KZ}$ index, but variable settings and coefficients in it remain to be discussed [19]. Financing constraints are related to external financing dependence which should be considered in the study of microcosmic factors.

The capital misallocation of listed companies is a systematic performance of financing, capital operation, and investment process. How to integrate financing and how to measure the dimension of capital operation are discussed. Available literatures focus on the effects of financial structure on capital misallocation and do empirical research of capital allocation efficiency under financing constraints and external financial dependence, while the studies about microcosmic affection factors of capital misallocation are very rare $[1,2]$. In fact, the analysis of the financial structure and investment performance in different financing constraints will be more accurate to explain the microcosmic factors of the impact of the capital misallocation from listed companies.

\section{Capital Misallocation and Data}

3.1. Capital Misallocation. The model includes the following variables:

$P_{s i}$ : the unit price of the products supplied by the firm $i$ for the industry $s$ production.

$Y_{s i}$ : the amount of the products supplied by firm $i$ for the industry $s$ production given by constant returns to scale production technology.

$w$ : the rate of wage.

$L_{s i}$ : the number of labor supplies of firm $i$ in sector $s$.

$K_{s i}$ : the capital investment of firm $i$ in industry $s$. And a firm reaches the capital level $\left(K_{s i}^{E}+K_{s i}^{I}=K_{s i}\right)$ via external financing $\left(K_{s i}^{E}\right)$ and internal capital holdings $\left(K_{s i}^{I}\right)$.

$R$ : the cost of capital.

$R^{c}$ : the purchase prices of capital good under financial constraints.

$\tau_{L i}:$ the labor price distortion.

$\tau_{K i}$ : the capital distortion.

$\tau_{s i}$ : the heterogeneity in capital rental rates distortion.

$A_{s i}$ : independent and identical distribution across firms with a cumulative distribution function $F(A)$.

$\alpha: 0<\alpha<1$, an industry-level technology parameter that determines the capital share of production.

$r^{c}$ : the average rental rate in the economy.

$\zeta_{s i}:$ Each firm is endowed with a fraction of the aggregate capital stock. $\zeta_{s i} K_{s}$ is the firm's capital holdings. There is an exogenously determined aggregate capital stock in each industry denoted with $K_{s}$. 
$\theta_{s i}:$ firm $i$ 's "financial market reputation" or its "financial pledgeability."

$\omega_{s i}:$ the industry capital inflows.

$\lambda_{s i}$ : a fraction of a firm's internal capital holdings.

$\gamma_{s i}$ : the distortions to capital-labor ratio.

For firms as rational people, investment decisions are at the trade-off between benefits and costs. The purpose of company production is to maximize profit; the profit of firm $i$ in industry $s$ can be formulated as

$$
\begin{aligned}
& \pi_{s i}=P_{s i} Y_{s i}-\left(1+\tau_{L i}\right) w L_{s i}-\left(1+\tau_{K i}\right) R K_{s i}, \\
& Y_{s i}=A_{s i} K_{s i}^{\alpha s} L_{s i}^{1-\alpha s} .
\end{aligned}
$$

Suppose that the capital required for producing of firm $i$ in industry $s$ is $K_{s i}$. And firm reaches the capital level $\left(K_{s i}^{E}+K_{s i}^{I}=K_{s i}\right)$ via external financing $\left(K_{s i}^{E}\right)$ and internal capital holdings $\left(K_{s i}^{I}\right)$. External financing is under the average rental rate in the economy $\left(r^{c}\right)$, firm's capital holdings $\left(\zeta_{s i} K_{s}\right)$, industry capital inflows $\left(\omega_{s i}\right)$, and financial pledgeability $\left(\theta_{s i}\right)$. When the total capital in industry $s$ is $K_{s}$, good producers can take up the capital which other firms need. The borrowing constraints $\left(B_{s i}\right)$ are

$$
B_{s i} \equiv\left(r^{c}\left(K_{s i}-\xi_{s i} K_{s}\right)-\omega_{s i}\right) \leq \theta_{s i} R^{c} K_{s i} .
$$

Every firm's constraint condition has the same cumulative distribution function $J(\omega, \xi, \theta)$. Inequality (3) implies that only a fraction $\left(\theta_{s i}\right)$ of external financing is available by borrowing. Under the financial constraints, firms can get the rest $\left(1-\theta_{s i}\right)$ of external capital under a capital rental distortion rate, $r^{c}\left(1+\tau_{s i}\right)$.

Two types of firms exist in each industry, denoted as investors and lenders. In equilibrium, it is impossible for any firm that is both a lender and an investor at the same time. Lender firms possess enough internal assets (capital and industrial consumables) to reach the optimum scale of capital investment; however, investor firms demand external finance to cover the optimum scale of investment.

A competitive equilibrium consists in the financial market where lender firms are indifferent between lending and selling the capital. This no-arbitrage condition leads to the equalization of the rental rate and the purchase prices of capital good, namely, to $r^{c}=R^{c}=R$.

In the equilibrium state (there is no arbitrage, $r^{c}=R^{c}=$ $R$; ignore labor price distortion $\tau_{L i}$ ), the objective function of profit of firm $i$ in industry $s$ for a nonfinancial constraints firm (a firm whose marginal cost of capital equals $R$ ) is

$$
\max _{P_{s i}, K_{s i}, L_{s i}} \pi_{s i} \equiv\left\{P_{s i} A_{s i} K_{s i}^{\alpha} L_{s i}^{1-\alpha}-w L_{s i}-R K_{s i}\right\}
$$

The function of profit for a financial constraints firm is

$$
\begin{aligned}
\max _{P_{s i}, K_{s i}^{E}, K_{s i}^{I}, L_{s i}} & \pi_{s i} \equiv\left\{P_{s i} A_{s i}\left(K_{s i}^{E}+K_{s i}^{I}\right)^{\alpha} L_{s i}^{1-\alpha}-w L_{s i}-R\left[\left(1+\tau_{s i}\right)\left(1-\theta_{s i}\right)+\theta_{s i}\right] K_{s i}^{E}-R K_{s i}^{I}\right\} \\
\text { s.t. } & R\left(K_{s i}-\xi_{s i} K_{s}\right)-\omega_{s i} \leq \theta_{s i} R K_{s i} .
\end{aligned}
$$

$1-\lambda_{s i}$ is a fraction of a firm's capital investment; define $\lambda_{s i}=\min \left\{\left(\omega_{s i}+R \zeta_{s i} K_{s}\right) / R K_{s i}, 1\right\}$. Firm $i$ can exploit its borrowing capacity until its upper limit $\theta_{s i}$. As a result, the fraction of firm's capital investment via borrowing is (1 $\left.\lambda_{s i}\right) \theta_{s i}$. Therefore, for a financial constraints firm, the profit maximization problem reduces to the following:

$$
\begin{aligned}
& \max _{P_{s i}, K_{s i}, L_{s i}} \pi_{s i} \equiv\left\{P_{s i} A_{s i}\left(K_{s i}^{E}+K_{s i}^{I}\right)^{\alpha} L_{s i}^{1-\alpha}-w L_{s i}\right. \\
& \left.-R\left[\lambda_{s i}+\left(1-\lambda_{s i}\right)\left[\left(1+\tau_{s i}\right)\left(1-\theta_{s i}\right)+\theta_{s i}\right]\right] K_{s i}\right\} .
\end{aligned}
$$

The objective function intimates that capital distortion and financing constraints affect the marginal cost of capital. The higher $\lambda_{s i}$, or the higher $\theta_{s i}$, the lower the marginal cost of production. If either $\lambda_{s i}=1$ or $\theta_{s i}=1$, the marginal cost of capital for firm $i$ equals $R$. If $\lambda_{s i}<1$ or $\theta_{s i}<1$, the marginal cost of capital is greater than $R$ as long as $\tau_{s i}>0$. Therefore, if a firm has $\lambda_{s i}<1, \theta_{s i}<1$, and $\tau_{s i}>0$, it is financially constrained.

Not only do internal financing, financial structure, and financial pledgeability influence the cost of financing, but also they affect capital-labor ratio.
According to (4), we can get the maximized profit for a nonfinancial constraints firm, by using first-order conditions:

$$
\begin{aligned}
& \frac{\partial \pi_{s i}}{\partial P_{s i}}=A_{s i} K_{s i}^{\alpha} L_{s i}^{1-\alpha}=0, \\
& \frac{\partial \pi_{s i}}{\partial K_{s i}}=\alpha P_{s i} A_{s i} K_{s i}^{\alpha-1} L_{s i}^{1-\alpha}-R=0, \\
& \frac{\partial \pi_{s i}}{\partial L_{s i}}=(1-\alpha) P_{s i} A_{s i} K_{s i}^{\alpha} L_{s i}^{-\alpha}-w=0 .
\end{aligned}
$$

Hence, profit maximizing capital-labor ratio for a nonfinancial constraints firm, $k_{s i}^{u}$, is derived as

$$
k_{s i}^{u} \equiv\left(\frac{K_{s i}}{L_{s i}}\right)^{u}=\frac{\alpha}{1-\alpha} \frac{w}{R} .
$$

According to (5), similarly available for a financial constraints firm the capital-labor ratio, $k_{s i}^{c}$, is found as

$$
\begin{aligned}
k_{s i}^{c} & \equiv\left(\frac{K_{s i}}{L_{s i}}\right)^{c} \\
& =\frac{\alpha}{1-\alpha} \frac{w}{R} \frac{1}{\left[\lambda_{s i}+\left(1-\lambda_{s i}\right)\left[\left(1+\tau_{s i}\right)\left(1-\theta_{s i}\right)+\theta_{s i}\right]\right]} .
\end{aligned}
$$


TABLE 1: The number of samples in different industries.

\begin{tabular}{lccccccc}
\hline & & \multicolumn{5}{c}{ Industry } \\
& Circulation & Petrochemical & Electron & Medicine and medical & Mechanical and electronic & Mining & Comprehensive \\
\hline Observations & 788 & 1203 & 856 & 985 & 1321 & 627 & 1316 \\
\hline
\end{tabular}

TABLE 2: Statistical description of capital misallocation (KLDistort ${ }_{i t}$ ) in different industries.

\begin{tabular}{|c|c|c|c|c|c|c|c|}
\hline & \multicolumn{7}{|c|}{ Industry } \\
\hline & Circulation & Petrochemical & Electron & Medicine and medical & Mechanical and electronic & Mining & Comprehensive \\
\hline Mean & 1.19 & 0.9 & 0.61 & 0.64 & 0.58 & 0.58 & 0.44 \\
\hline Median & 0.4 & 0.48 & 0.36 & 0.24 & 0.2 & 0.32 & 0.01 \\
\hline Standard deviation & 2.9 & 1.91 & 1.84 & 1.93 & 2.07 & 2.23 & 2.12 \\
\hline Minimum & -6.57 & -6.43 & -6.48 & -5.94 & -6.85 & -6.93 & -6.47 \\
\hline Maximum & 7.82 & 5.82 & 5.19 & 6.94 & 6.77 & 6.68 & 7.31 \\
\hline Quartile 50\% & 0.4 & 0.48 & 0.36 & 0.24 & 0.2 & 0.32 & 0.01 \\
\hline Quartile 75\% & 2.33 & 1.84 & 1.52 & 1.48 & 1.43 & 1.7 & 1.36 \\
\hline Observations & 788 & 1203 & 856 & 985 & 1321 & 627 & 1316 \\
\hline
\end{tabular}

Note: to calculate capital misallocation, $\tau_{s i}$ is weighted average of capital cost, $\theta_{s i}$ is calculation result using financial pledgeability, and $\lambda_{s i}$ is (current assets current liabilities)/(current liabilities) $)_{i t}$.

Using (9), we can infer distortions to the capital-labor ratio for differentiated firms with binding financing constraints as

$$
\begin{aligned}
& 1+\underbrace{\tau_{s i}\left(1-\theta_{s i}\right)\left(1-\lambda_{s i}\right)}_{=\gamma_{s i}}=\frac{\alpha}{1-\alpha} \frac{w}{R} \frac{L_{s i}}{K_{s i}}, \\
& \gamma_{s i}=\tau_{s i}\left(1-\theta_{s i}\right)\left(1-\lambda_{s i}\right)=\frac{\alpha}{1-\alpha} \frac{w}{R} \frac{L_{s i}}{K_{s i}}-1 .
\end{aligned}
$$

$R$ is cost of capital (generally it is $10 \%$ in the study). High labor intensive manufacturing firms have higher cost of capital distortion. Equation (10) proves that distortions to capital-labor ratio $\left(\gamma_{s i}\right)$ have three components. The first component $\left(\tau_{s i}\right)$ is the heterogeneity in capital rental rates from financial constraints. The second component $\left(\theta_{s i}\right)$ is financial pledgeability; the lower financial pledgeability the firms have, the poorer the return on investment they have. Finally, the third component $\left(\lambda_{s i}\right)$ is associated with the ability to finance investment project using internal liquidity $[20,21]$.

3.2. The Data. The data covers fiscal years 2003 to 2014 for A-shares of Chinese nonfinancial firms that were listed on the Shanghai and Shenzhen stock exchange. And we screen and process the data according to the following standards: (1) excluding the samples with many missing values in the company's financial data; (2) weeding out the firms with abnormal accounting data and percentage change in share price, along with equability in the value of the company's assets; (3) deleting the firms which are listed less than a year and the firms whose profitability is more volatile. Besides that, we deal with all continuous variables on the top and bottom $1 \%$ by Winsorize. Finally, we achieve 7096 observations of 646 listed companies during 11 years (Table 1). The financial data in this paper is from Wind Database and CSMAR Database.

Table 2 is the statistical description of capital misallocation $\left(\mathrm{KLDistort}_{i t}\right)$ in different industries. The mean, median, and quartile $50 \%$ in seven industries are greater than zero, which implies that more than half of firms have capital misallocation (KLDistort ${ }_{i t}>0$ means that capital misallocation exists in firms). The difference of maximum and minimum between industries is obvious.

Equation (10) proves that capital misallocation $\left(\text { KLDistort }_{i t}\right)_{\text {consisted of capital rental rates, financial }}$ liquidity, and financial pledgeability. And it is caused by the difference of capital rental rates, financial liquidity, and financial pledgeability in different firms. Testing the impact of financial liquidity and financial pledgeability on company capital misallocation is the core of our study.

Table 3 is the sensitivity analysis table about capital misallocation $\left(\tau_{s i}\left(1-\theta_{s i}\right)\left(1-\lambda_{s i}\right)\right)$. We can find that corporate capital misallocation is very sensitive to financial pledgeability, cost of capital, and liquidity.

When cost of capital is 0.1 , financial pledgeability is poor, and capital misallocation usually does not exist, while it rarely happens. When financial pledgeability is 2 , all values are positive except the case that capital rental rate is 0.1 (for details, see Table 3 and Figure 1). It implies that financial pledgeability has a great impact on capital misallocation.

Figure 1 is a tendency chart of capital misallocation $\left(\tau_{s i}(1-\right.$ $\left.\left.\theta_{s i}\right)\left(1-\lambda_{s i}\right)\right)$. The trend lines in the graph are Percentile $30 \%$, mean, and Percentile 60\%. The Percentile 30\% and mean trend lines have a downward tendency after 2009, while the Percentile $60 \%$ trend line has upward tendency. Because many sample values are embodied in the Percentile $60 \%$, we cannot ignore the problem of capital misallocation in the listed companies.

\section{Empirical Study}

First of all, in order to control the problem of multicollinearity between variables, this paper does descriptive statistics for each variable and investigates the correlations of variables. After that, we employ panel data models to empirically 
TABLE 3: Sensitivity analysis table of capital misallocation $\left(\tau_{s i}\left(1-\theta_{s i}\right)\left(1-\lambda_{s i}\right)\right)$.

\begin{tabular}{|c|c|c|c|c|c|c|}
\hline \multirow{3}{*}{ Cost of capital } & \multicolumn{6}{|c|}{ Financial pledgeability } \\
\hline & 12 & 10 & 8 & 6 & 4 & 2 \\
\hline & $\ln (12)$ & $\ln (10)$ & $\ln (8)$ & $\ln (6)$ & $\ln (4)$ & $\ln (2)$ \\
\hline 0.1 & -0.55 & -0.45 & -0.35 & -0.25 & -0.15 & -0.05 \\
\hline 0.11 & -0.09 & -0.079 & -0.065 & -0.048 & -0.023 & 0.019 \\
\hline 0.12 & -0.107 & -0.094 & -0.078 & -0.057 & -0.028 & 0.022 \\
\hline 0.13 & -0.125 & -0.11 & -0.091 & -0.067 & -0.033 & 0.026 \\
\hline 0.14 & -0.146 & -0.128 & -0.106 & -0.078 & -0.038 & 0.03 \\
\hline 0.15 & -0.167 & -0.147 & -0.121 & -0.089 & -0.043 & 0.035 \\
\hline 0.16 & -0.178 & -0.156 & -0.13 & -0.095 & -0.046 & 0.037 \\
\hline 0.17 & -0.202 & -0.177 & -0.147 & -0.108 & -0.053 & 0.042 \\
\hline
\end{tabular}

Note: in the calculation, assume that the higher the cost of capital is, accordingly the lower the liquidity ratio is. For example, when cost of capital changes from 0.12 to 0.11 , liquidity ratios change from 0.5 to 0.55 . Numerous domestic and international studies assume the cost of capital is $10 \%$, so we assume it starts from 0.1 .

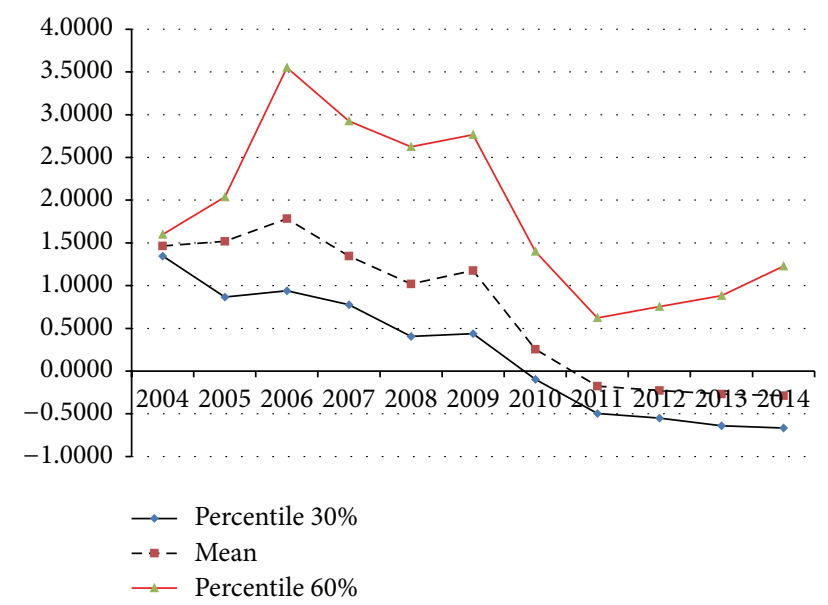

Figure 1: Tendency chart of capital misallocation $\left(\tau_{s i}\left(1-\theta_{s i}\right)(1-\right.$ $\left.\lambda_{s i}\right)$ ). Note: the reason why we choose Percentile $30 \%$, mean, and Percentile $60 \%$ is that misallocation mostly distributes between 40 and $70 \%$ in frequency distributing graph.

analyze the impact of microcosmic factors, financial liquidity, financial pledgeability, and other controlled variables on capital misallocation and test whether different external finance dependence affects capital misallocation.

4.1. Variable. According to available literatures and theoretical analysis, all the variables used in this paper for studying the impact of financial pledgeability on capital misallocation can be found in Table 4 .

4.1.1. Financial Pledgeability. It is popular in many overseas researches that measure firm's financial pledgeability using Standard \& Poor's Credit Rating data (according to the Standard \& Poor's Compustat Database, firm credit ratings in the sample range from $C=2$ to $A A A=24$, with $C=2$ being the worst credit rating and $A A A=24$ being the best credit rating) $[2,8]$. Because the listed companies in China lack the credit rating data, we measure firm's financial pledgeability

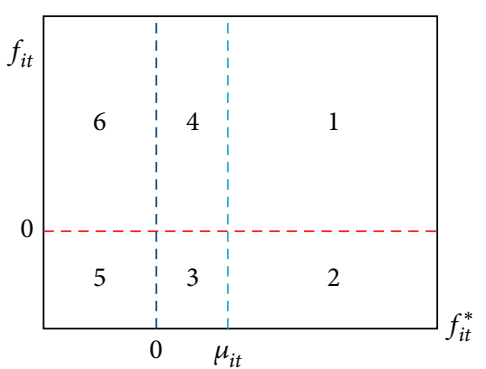

FIGURE 2: A classification of firms on the basis of their solvency and liquidity conditions.

on the basis of firm's solvency and liquidity conditions (see Figure 2) [22, 23].

A firm's liquidity at time $t$ is $f_{i t}$ :

$$
f_{i t}=y_{i t}-e_{i t} \quad i=1,2, \ldots, n .
$$

This paper measures it in each period $t$ as the surplus of financial inflows $y_{i t}$ over financial outflows $e_{i t}$.

The solvency of a firm may be measured by its net worth $\left(f_{i t}^{*}\right)$, defined as the sum of its expected surpluses and deficits over a given time horizon $T_{i}$, discounted through the nominal interest rate $r$; namely,

$$
f_{i t}^{*}=\sum_{s=0}^{T_{i}} \frac{E_{t-1}\left[f_{i t+s}\right]}{(1+r)^{s}} \quad 1,2, \ldots, n,
$$

where $E_{t-1}[\cdot]$ denotes the conditional expectation operator based upon information available at the end of period $t-1, r$ is nominal interest rate, and $T_{i} \geq 1$. If $f_{i t}^{*} \geq 0$, firm $i$ is sustainable; if $f_{i t}^{*}<0$, firm $i$ is virtually insolvent or faces recombination.

In order to explore the dynamics of $\left(f_{i t}, f_{i t}^{*}\right)$, this paper establishes the extrapolative expectations $f_{t+1}$ under financial instability:

$$
f_{t+1}=f_{t}-\alpha_{f}\left(f_{t}^{*}-\mu\right),
$$

where $\alpha_{f}>0$ represents the speed of reaction of firm's liquidity index to discrepancies in the solvency index and the safety 
TABLE 4: Variables' definitions.

\begin{tabular}{|c|c|c|c|}
\hline Variables & Name & Description & Calculation \\
\hline Dependent variable & KLDistort $_{i t}$ & $\begin{array}{c}\text { Capital misallocation } \\
\text { ratio }\end{array}$ & $\tau_{s i}\left(1-\theta_{s i}\right)\left(1-\lambda_{s i}\right)$ \\
\hline \multirow[t]{2}{*}{ Independent variables } & liquidity $_{i t}$ & Financial liquidity & $\begin{array}{c}\text { (Current assets - current } \\
\text { liabilities }) /(\text { current liabilities })_{i t}\end{array}$ \\
\hline & pledgeability $_{i t}$ & Financial pledgeability & See details in (1) \\
\hline \multirow{8}{*}{ Control variables } & $\operatorname{Ln}(A)$ & Firm size & LN (total assets (ten thousand yuan)) \\
\hline & Profitability $_{i t}$ & Profitability & $\begin{array}{l}\text { (Total operating incomes - total } \\
\text { operating costs)/total assets }\end{array}$ \\
\hline & Debt structure & Debt structure & Total long-term debts/total debts \\
\hline & IFA & $\begin{array}{l}\text { Investment in fixed } \\
\text { assets }\end{array}$ & $\begin{array}{c}\mathrm{LN}\left(\mathrm{FA}_{t}-\mathrm{FA}_{t-1}\left(1+\pi_{t}\right)+\mathrm{dep}_{t}\right) \\
\mathrm{FA}_{t} \text { is fixed assets; } \pi_{t} \text { is rate of } \\
\text { inflation; } \text { dep }_{t} \text { is depreciation }\end{array}$ \\
\hline & EFD & $\begin{array}{l}\text { External finance } \\
\text { dependence }\end{array}$ & See details in (2) \\
\hline & Industry & Industry & $\begin{array}{l}\text { Dummy, if firm belongs to this industry, } \\
\text { industry }=1 \text {; otherwise, industry }=0\end{array}$ \\
\hline & Year & Year & $\begin{array}{l}\text { Dummy, if data belongs to this year, year } \\
=1 \text {; otherwise, year }=0\end{array}$ \\
\hline & IP & Innovation performance & See details in (3) \\
\hline
\end{tabular}

TABLE 5: Distribution of companies at various $\left(f_{i t}, f_{i t}^{*}\right)$ values in different time.

\begin{tabular}{lccccccc}
\hline Time & Description & Region 1 & Region 2 & Region 3 & Region 4 & Region 5 & Region 6 \\
\hline \multirow{2}{*}{$T=1$} & Number & 1245 & 2899 & 1863 & 1197 & 962 & 14 \\
& Proportion (\%) & 15.22 & 35.44 & 22.78 & 14.63 & 11.76 & 0.17 \\
\hline \multirow{2}{*}{$T=2$} & Number & 1107 & 2632 & 1976 & 1237 & 1203 & 25 \\
& Proportion (\%) & 13.53 & 32.18 & 24.16 & 15.12 & 14.71 & 0.31 \\
\hline \multirow{2}{*}{$T=3$} & Number & 936 & 2249 & 2138 & 1344 & 1441 & 12 \\
& Proportion (\%) & 11.44 & 27.49 & 26.14 & 16.43 & 17.62 & 0.88 \\
\hline
\end{tabular}

margin and $\mu$ is the safety margin at time $t$. And when doing empirical analysis, this paper sets the coefficient as 0.25 [23]. But the value of coefficient needs to be further investigated.

The vertical dashed line drawn at $f_{i t}^{*}=0$ is the solvency barrier. The firm in its left has a negative net worth and is virtually insolvent. The horizontal dashed line $f_{i t}=0$ is the liquidity line. The firm beneath it has financial deficit. We assume that each firm, in order to avoid the risk of bankruptcy, chooses a value that ensures its margin and net worth sufficiently higher than zero. Let us call $u_{i t}$ the safety margin. $f_{i t}^{*}=u_{i t}$ is the safety line. According to Figure 2, there are six types of financial structures. Firms in region 1 are called hyperhedge as they do not have either liquidity or solvency problems $\left(f_{i t}>0, f_{i t}^{*}>u_{i t}\right)$. Firms in region 2 are speculative as they have liquidity problems but do not perceive solvency problems $\left(f_{i t}<0, f_{i t}^{*}>u_{i t}\right)$. Firms in region 3 are hyperspeculative, because they have both liquidity and solvency problems $\left(f_{i t}<0,0<f_{i t}^{*}<u_{i t}\right)$. Firms in region 4 are hedge firms as they do not have liquidity problems but may incur in solvency problems $\left(f_{i t}>0,0<\right.$ $\left.f_{i t}^{*}<u_{i t}\right)$. Firms in region 5 and region 6 are highly distressed financial firms. The former lack both liquidity and solvency $\left(f_{i t}<0, f_{i t}^{*}<0\right)$. But the latter have hopes of survival, their liquidity is higher than marginal value, and the solvency is lower than marginal value $\left(f_{i t}>0, f_{i t}^{*}<0\right)$. If the firm belongs to region 1 , pledgeability $=12$; if it belongs to region 2 , pledgeability $=10$; if it belongs to region 4 , pledgeability $=8$; if it belongs to region 3 , pledgeability $=6$; if it belongs to region 6 , pledgeability $=4$; if it belongs to region 5 , pledgeability $=2$.

Table 5 is the number of companies at six types of financial structures in different time levels on $\left(f_{i t}, f_{i t}^{*}\right)$ (the implication of six types of financial structures is detailedly shown in Figure 2). When $T=1$, the proportion of companies in safe and relatively safe regions (regions 1 and 4) is only $29.85 \%$, which in much dangerous regions (regions 3 and 5) is only $34.54 \%$. When $T=2$, the proportion of companies in safe and relatively safe regions (regions 1 and 4 ) is only $28.65 \%$, which in much dangerous regions (regions 3 and 5) is only $38.87 \%$. When $T=3$, the proportion of companies in safe and relatively safe regions (regions 1 and 4) is only $27.87 \%$, which in much dangerous regions (regions 3 and 5) is only $43.76 \%$. These figures prove that corporate capital misallocation is extremely serious under the perspective of capital operation.

By comparing the numbers at $T=1, T=2$, and $T=3$, we can find that the number of companies at safe region (region 1) is decreasing, and the number of companies at 
relatively safe region (region 4) is increasing. On account of the fact that the solvency of firms in region 4 is between 0 and safety margin, the situation is not optimistic.

4.1.2. External Finance Dependence (EFD). Financing constraints are relative to firm's external finance dependence. Rajan and Zingales considered firm's external finance dependence as (operating cash flow - capital expenditure)/capital expenditure [24]. The firm depends less on external finance if its value of (operating cash flow - capital expenditure)/capital expenditure is below average external finance dependence in industry. Group firms according to the differences between firms and industry. Firms with low level of external finance dependence have EFD = 3, firms with intermediate level of external finance dependence have $\mathrm{EFD}=2$, and firms with high level of external finance dependence have EFD $=1$.

4.1.3. Innovation Performance. Financial structure is relative to research and development ability (generally, poor R\&D capability is associated with labor intensive production). The characteristics of research and development investments are long cycle, high extent of asymmetric information, and great uncertainty. Research and development investments which mainly come from firm's own capital holdings are more sensitive to financing constraints than fixed investments. With binding financial constraints, the rational firms allocate more capital to production, which leads to the lack of research and development investments as well as the unbalanced investment.

To measure the innovation performance, we draw lessons from Vassalou and Apedjinou and assume that the production function is a Cobb-Douglas production function [25]:

$$
Y_{i t}=A_{i t} K_{i t}^{a_{1 i}} L_{i t}^{a_{2 i}}
$$

where $Y_{i t}$ is the production of firm $i$ in time $t ; A_{i t}$ is technical contribution of firm $i$ in time $t ; K_{i t}^{a_{1 i}}$ is the total capital of firm $i$ in time $t$; and $L_{i t}^{a_{2 i}}$ is labor input of firm $i$ in time $t$.

Assume that there are no intermediate goods in a competitive labor market, and then the gross profit margin (GPM) is

$$
\begin{aligned}
\mathrm{GPM}_{i t} & =Y_{i t}-L_{i t} \mathrm{MP}_{L_{i t}}, \\
\mathrm{MP}_{L_{i t}} & =a_{2 i} A_{i t} K_{i t}^{a_{1 i}} L_{i t}^{a_{2 i}-1}, \\
\mathrm{GPM}_{i t} & =\left(A_{i t}-a_{2 i} A_{i t}\right) K_{i t}^{a_{1 i}} L_{i t}^{a_{2 i}},
\end{aligned}
$$

where $\mathrm{GMP}_{i t}$ is gross profit margin of firm $i$ in time $t$; $\mathrm{MP}_{L_{i t}}$ is marginal product of firm $i$ in time $t$; and $A_{i t}-$ $a_{2 i} A_{i t}$ is corporate innovation. Get (19) under logarithmically processing both sides of (18).

$$
\ln \mathrm{GPM}_{i t}=\ln \mathrm{CI}_{i t}+a_{1 i} \ln K_{i t}+a_{2 i} \ln L_{i t} .
$$

If all $a_{1 i}$ and $a_{2 i}$ in different firms are the same, (19) can be written as

$$
\ln \mathrm{GPM}_{i t}=\ln \mathrm{CI}_{i t}+a_{1} \ln K_{i t}+a_{2} \ln L_{i t},
$$

where $K_{i t}$ and $L_{i t}$ denote total capital and total employees, respectively. It is difficult to estimate $\mathrm{CI}_{i t}$, so we can get (21) according to (19):

$$
\ln \mathrm{CI}_{i t}=\ln \mathrm{GPM}_{i t}-\left(\beta_{1} \ln K_{i t}+\beta_{2} \ln L_{i t}\right)=\alpha+\varepsilon_{i t} .
$$

In order to overcome the difference of variables' units, we can obtain $\widehat{\alpha}+e_{i t}$ through (21).

$$
\ln \left(\frac{\mathrm{GPM}_{i t}}{\overline{\mathrm{GPM}_{t}}}\right)=\widehat{\alpha}+\beta_{1} \ln \left(\frac{K_{i t}}{\overline{K_{t}}}\right)+\beta_{2} \ln \left(\frac{L_{i t}}{L_{t}}\right)+\varepsilon_{i t},
$$

where $\widehat{\alpha}+e_{i t}$ is all factors affecting GPM except total assets and labor. $\widehat{\alpha}+e_{i t}$ is the innovation performance of firms.

4.2. Methodology. In order to test the microcosmic factors that influence the allocation of resources under different external financing dependence, this paper constructs (model-1), (model-2), (model-3), and (model-4):

$$
\begin{aligned}
\text { KLDistort }_{i t}= & a_{s t}+\phi_{1}^{*} \times \text { Fin.liquidity }_{i t}+\beta \\
& \times \text { Controls }_{i t}+\sum_{j} \text { Indus }_{j} \\
& +\sum_{t} \text { Year }_{t}+\varepsilon_{i t}, \\
\text { KLDistort }_{i t}= & a_{s t}+\phi_{2}^{*} \times \text { Fin.pledgeability }_{i t} \\
& +\beta \times \text { Controls }_{i t}+\sum_{j} \text { Indus }_{j} \\
& +\sum_{t} \text { Year }_{t}+\varepsilon_{i t}, \\
\text { KLDistort }_{i t}= & a_{s t}+\phi_{1}^{*} \times \text { Fin.liquidity }_{i t} \times \text { EFD }_{i} \\
& +\beta \times \text { Controls }_{i t}+\sum_{j} \text { Indus }_{j} \\
& +\sum_{t} \text { Year }_{t}+\varepsilon_{i t}, \\
& +\sum_{j} \text { Indus }_{j}+\sum_{t} \text { Year }_{t}+\varepsilon_{i t}, \\
\text { KLDistort }_{i t}= & a_{s t}+\phi_{2}^{*} \times \text { Fin.pledgeability }_{i t} \\
& \times \text { EFD }_{i}+\beta \times \text { Controls }_{i t} \\
&
\end{aligned}
$$

where KLDistort Kit $=\gamma_{i t}=\left(\alpha_{s} /\left(1-\alpha_{s}\right)\right)(w / R)\left(L_{i t} / K_{i t}\right)-1$ is capital misallocation ratio of firm $i ; a_{s t}$ is fixed effects for the industry; $\mathrm{EFD}_{i}$ is external finance dependence; Fin.liquidity ${ }_{i t}$ is financial liquidity; pledgeability ${ }_{i t}$ is financial pledgeability; and Controls ${ }_{i t}$ is controlled variables.

\subsection{Empirical Results}

4.3.1. Descriptive Statistics of Variables. Table 6 is descriptive statistics about the annual data of all the firms' explanatory variables and control variables. According to the high, intermediate, and low level of external finance dependence, it 
TABLE 6: Descriptive statistics of main variables.

\begin{tabular}{|c|c|c|c|c|c|c|}
\hline \multirow[t]{2}{*}{ Variables } & \multicolumn{2}{|c|}{$\begin{array}{l}\mathrm{EFD}=3 \text { (high level of external } \\
\text { finance dependence) }\end{array}$} & \multicolumn{2}{|c|}{$\begin{array}{l}\mathrm{EFD}=2 \text { (intermediate level of } \\
\text { external finance dependence) }\end{array}$} & \multicolumn{2}{|c|}{$\begin{array}{l}\mathrm{EFD}=1 \text { (low level of external } \\
\text { finance dependence) }\end{array}$} \\
\hline & Mean & Observations & Mean & Observations & Mean & Observations \\
\hline Financial liquidity & 0.322 & 3542 & 0.547 & 1293 & 0.862 & 2256 \\
\hline $\begin{array}{l}\text { Financial } \\
\text { pledgeability }\end{array}$ & 5.63 & 3543 & 6.38 & 1294 & 8.74 & 2255 \\
\hline Firm size & 11.75 & 3543 & 12.26 & 1294 & 13.72 & 2255 \\
\hline Profitability & 5.37 & 3543 & 9.21 & 1294 & 12.33 & 2257 \\
\hline Debt structure & 0.672 & 3544 & 0.534 & 1295 & 0.39 & 2257 \\
\hline $\begin{array}{l}\text { Investment in fixed } \\
\text { assets }\end{array}$ & 6.34 & 3544 & 7.66 & 1295 & 5.46 & 2257 \\
\hline $\begin{array}{l}\text { Innovation } \\
\text { performance }\end{array}$ & 0.121 & 3537 & 0.377 & 1286 & 0.614 & 2245 \\
\hline
\end{tabular}

TABLE 7: Pearson correlation coefficient between main variables.

\begin{tabular}{|c|c|c|c|c|c|c|c|}
\hline Variables & $\begin{array}{l}\text { Financial } \\
\text { liquidity }\end{array}$ & $\begin{array}{c}\text { Financial } \\
\text { pledgeability }\end{array}$ & Firm size & Profitability & Debt structure & $\begin{array}{l}\text { Investment in } \\
\text { fixed assets }\end{array}$ & $\begin{array}{l}\text { Innovation } \\
\text { performance }\end{array}$ \\
\hline $\begin{array}{l}\text { Financial } \\
\text { liquidity }\end{array}$ & 1 & & & & & & \\
\hline $\begin{array}{l}\text { Financial } \\
\text { pledgeability }\end{array}$ & $\begin{array}{c}0.922^{* * *} \\
-4.265 \\
\end{array}$ & 1 & & & & & \\
\hline Firm size & $\begin{array}{l}0.434^{*} \\
-2.015 \\
\end{array}$ & $\begin{array}{l}0.563^{* *} \\
-2.236 \\
\end{array}$ & 1 & & & & \\
\hline Profitability & $\begin{array}{c}0.722^{* * *} \\
-3.565\end{array}$ & $\begin{array}{c}0.566^{* * *} \\
-4.912\end{array}$ & $\begin{array}{l}0.618^{*} \\
-2.025 \\
\end{array}$ & 1 & & & \\
\hline Debt structure & $\begin{array}{c}0.119^{*} \\
-1.945 \\
\end{array}$ & $\begin{array}{c}-0.721^{* * *} \\
(-3.653)\end{array}$ & $\begin{array}{c}0.794^{* * *} \\
-4.135 \\
\end{array}$ & $\begin{array}{l}0.093^{* *} \\
-2.987 \\
\end{array}$ & 1 & & \\
\hline $\begin{array}{l}\text { Investment in } \\
\text { fixed assets }\end{array}$ & $\begin{array}{c}-0.279^{* * *} \\
(-3.339)\end{array}$ & $\begin{array}{c}0.493^{* * *} \\
-3.756\end{array}$ & $\begin{array}{c}0.831^{* * *} \\
-5.343\end{array}$ & $\begin{array}{c}0.435 \\
-1.484\end{array}$ & $\begin{array}{c}0.447^{* * *} \\
-3.351\end{array}$ & 1 & \\
\hline $\begin{array}{l}\text { Innovation } \\
\text { performance }\end{array}$ & $\begin{array}{c}0.637^{* * *} \\
-4.895\end{array}$ & $\begin{array}{l}0.344^{* *} \\
-2.248\end{array}$ & $\begin{array}{c}0.239^{* * *} \\
-3.776\end{array}$ & $\begin{array}{c}0.776^{* * *} \\
-5.322\end{array}$ & $\begin{array}{l}-0.311^{* *} \\
(-2.214)\end{array}$ & $\begin{array}{c}-0.213^{* * *} \\
(-4.674)\end{array}$ & 1 \\
\hline
\end{tabular}

Note: $(1) * * *$ indicates statistical significance at the 0.01 level; $* *$ indicates statistical significance at the 0.05 level; $*$ indicates statistical significance at the 0.10 level.

displays the mean and sample variables of three firm groups (the proportion for the companies under high level of external financing dependence is about $49.8 \%$; the intermediate accounts for about $16.148 \%$; percentage of the low is $31.8 \%$ ) in order to run a comparative analysis. The statistical results reveal that, in different external financing dependence, there is a significant difference between the variables. Under the high level of external financing dependence, firms' variable indexes are significantly inferior to those under the low level. Eberhart et al. considered that the general labor intensive firms have low innovation abilities, whose earnings are uncertain and fluctuant and whose external finance dependence is quite high [26]. The high level of external finance dependence firms is with a proportion of about $49.8 \%$. Improving the firms' innovation abilities is the main way to reduce the external finance dependence and improve the allocation efficiency.

Table 7 is the results of Pearson correlation coefficient between variables. Results reveal that, except that the correlation between fixed assets investment and profitability is not significant (the problem about fixed assets investment impacts profitability; we tested it when considering time delay problem, but it is not significant, either), other variables display significantly positive and negative relationships. The financial liquidity and financial pledgeability are highly positively related; in addition, other indicators are significantly correlated to the financial liquidity and financial pledgeability. In order to avoid the problem of multicollinearity, these variables are properly controlled in panel data analysis.

4.3.2. Multiple Regression Analysis. On the basis of (model-3), we study the impact of the financial liquidity on capital misallocation in various external finance dependence first. The purpose of this study is problems under different external finance dependence, so the regression results of (model-1) and (model-2) are not shown (the regression 
TABLE 8: Regression results of (model-3).

\begin{tabular}{|c|c|c|c|c|c|c|}
\hline \multirow{2}{*}{$\begin{array}{l}\text { Variables } \\
\text { liquidity }_{i t} \times \operatorname{EFD}(3)\end{array}$} & \multicolumn{6}{|c|}{$\tau_{s i}\left(1-\theta_{s i}\right)\left(1-\lambda_{s i}\right)$} \\
\hline & $\begin{array}{c}0.003^{* *} \\
(2.34) \\
\end{array}$ & $\begin{array}{c}0.0017^{* *} \\
(2.29)\end{array}$ & & & & \\
\hline liquidity $_{i t} \times \mathrm{EFD}(2)$ & & & $\begin{array}{c}-0.0016^{* *} \\
(-2.48) \\
\end{array}$ & $\begin{array}{c}-0.0011^{* *} \\
(-2.41)\end{array}$ & & \\
\hline liquidity $_{i t} \times \mathrm{EFD}(1)$ & & & & & $\begin{array}{c}-0.3973^{* * *} \\
(-4.37) \\
\end{array}$ & $\begin{array}{c}-0.3318^{* * *} \\
(-3.92) \\
\end{array}$ \\
\hline $\operatorname{Ln}(A)$ & & $\begin{array}{c}-0.346^{* * *} \\
(-3.25) \\
\end{array}$ & & $\begin{array}{c}-0.388^{* * *} \\
(-3.59) \\
\end{array}$ & & $\begin{array}{c}-0.712^{* * *} \\
(-4.17) \\
\end{array}$ \\
\hline Profitability $_{i t}$ & & $\begin{array}{c}-0.0613^{* *} \\
(-1.88)\end{array}$ & & $\begin{array}{c}-0.173^{*} \\
(-1.92)\end{array}$ & & $\begin{array}{c}-0.337^{* *} \\
(-2.53)\end{array}$ \\
\hline Debt structure & & $\begin{array}{c}0.526^{* * *} \\
(3.77)\end{array}$ & & $\begin{array}{c}0.673^{* *} \\
(2.53)\end{array}$ & & $\begin{array}{c}0.706^{* *} \\
(2.62)\end{array}$ \\
\hline IFA & & $\begin{array}{r}0.1176 \\
(1.26) \\
\end{array}$ & & $\begin{array}{c}0.2396 \\
(1.42) \\
\end{array}$ & & $\begin{array}{l}0.489 \\
(1.33) \\
\end{array}$ \\
\hline IP & & $\begin{array}{c}-1.004^{* * *} \\
(-4.13) \\
\end{array}$ & & $\begin{array}{c}-0.952^{* * *} \\
(-3.13) \\
\end{array}$ & & $\begin{array}{c}-0.894^{* * *} \\
(-3.97)\end{array}$ \\
\hline Industry & Yes & Yes & Yes & Yes & Yes & Yes \\
\hline Year & Yes & Yes & Yes & Yes & Yes & Yes \\
\hline$R$-sq: within & 0.436 & 0.497 & 0.46 & 0.532 & 0.482 & 0.519 \\
\hline Rho & 0.568 & 0.608 & 0.577 & 0.635 & 0.559 & 0.6384 \\
\hline $\mathrm{chi}^{2}$ & 275.77 & 316.39 & 189.55 & 289.33 & 179.84 & 211.02 \\
\hline Hausman & 0.0000 & 0.0000 & 0.0000 & 0.0000 & 0.0000 & 0.0000 \\
\hline
\end{tabular}

Note: $(1) * * *$ indicates statistical significance at the 0.01 level; $* *$ indicates statistical significance at the 0.05 level; $*$ indicates statistical significance at the 0.10 level. (2) Brackets for $t$ value. (3) $\mathrm{EFD}$ (3) is high level of external finance dependence, $\operatorname{EFD}(2)$ is intermediate level of external finance dependence, and $\mathrm{EFD}(1)$ is low level of external finance dependence.

analysis of (model-1) and (model-2) indicates that the coefficient of liquidity it $_{\text {is }}-1.381^{* * *}(-4.362)$ and the coefficient of pledgeability $i t$ is $-1.753^{* * *}(-3.914)$, in which “***" indicates statistical significance at the 0.01 level, so when the financial liquidity is stronger and the financial pledgeability is higher, the ratio of capital misallocation is lower); the regression results are shown in Table 8. Regardless of whether to join other control variables, the coefficient of liquidity $_{i t} \times \mathrm{EFD}(3)$ (financial liquidity and external financing dependence cross-multiplication term) is significantly positive; however, the coefficients of liquidity ${ }_{i t} \times \operatorname{EFD}(2)$ and liquidity $_{i t} \times \operatorname{EFD}(1)$ are significantly negative. So when the financial liquidity is stronger and the external financing dependence is lower, capital misallocation ratio is lower. This result is consistent with numerous overseas research conclusions $[2,8,27]$. The regression coefficients of $\operatorname{Ln}(A)$, Profitability ${ }_{i t}$, and IP are significantly negative, while the regression coefficient of debt structure is significantly positive. Compared to labor intensive firms, the firms with high innovation abilities have stronger profitability, superior financial liquidity, and better financial pledgeability, thus reducing corporate capital misallocation [2, 25]. Moreover, many domestic researches found that the listed companies with large-scale assets and strong profitability easily obtain bank loans and equity financing, while violating the principle of matching assets (payable account mainly relies on long-term liabilities, yet capital gap mostly depends on shortterm liabilities). The regression coefficient of investment in fixed assets (IFA) is positive but not significant. Some domestic researches pointed out that IFA contribute to improving the efficiency of resource allocation, but through the data analysis in articles, capital supplies and output benefits of IFA in many firms remain to be fully explored.

On the basis of (model-4), we study the impact of the financial pledgeability on capital misallocation under various external finance dependence; the regression results are shown in Table 9. Regardless of whether to join other control variables, the coefficients of financial pledgeability and external financing dependence cross-multiplication terms, pledgeability ${ }_{i t} \times \operatorname{EFD(3)}$, pledgeability $_{i t} \times \operatorname{EFD}(2)$, and pledgeability ${ }_{i t} \times \operatorname{EFD}(1)$, are significantly positive. So firms in high financial pledgeability are unaffected by the external financing dependence and have low rate of capital misallocation. This result is consistent with numerous overseas research conclusions [2, 8, 27]. The regression coefficients of $\operatorname{Ln}(A)$, Profitability ${ }_{i t}$, and IP are significantly negative, while the regression coefficient of debt structure is significantly positive. The direction of control variables regression coefficient and significant results are similar to Table 8, but in low level of external financing dependence, the regression coefficient of IFA is significantly negative. 
TABLE 9: Regression results of (model-4).

\begin{tabular}{|c|c|c|c|c|c|c|}
\hline Variables & & & $\tau_{s i}(1-$ & $\left.\lambda_{s i}\right)$ & & \\
\hline pledgeability $_{i t} \times \operatorname{EFD(3)}$ & $\begin{array}{c}-0.037^{* *} \\
(-2.46)\end{array}$ & $\begin{array}{c}-0.028^{* *} \\
(-2.41)\end{array}$ & & & & \\
\hline pledgeability $_{i t} \times \operatorname{EFD}(2)$ & & & $\begin{array}{c}-0.059^{* * *} \\
(-3.74) \\
\end{array}$ & $\begin{array}{c}-0.076^{* * *} \\
(-3.37) \\
\end{array}$ & & \\
\hline pledgeability $_{i t} \times \mathrm{EFD}(1)$ & & & & & $\begin{array}{c}-0.4673^{* * *} \\
(-4.37) \\
\end{array}$ & $\begin{array}{c}-0.3726^{* * *} \\
(-3.61) \\
\end{array}$ \\
\hline $\operatorname{Ln}(A)$ & & $\begin{array}{c}-0.782^{* * *} \\
(-3.74) \\
\end{array}$ & & $\begin{array}{c}-0.815^{* * *} \\
(-4.10) \\
\end{array}$ & & $\begin{array}{c}-1.123^{* * *} \\
(-3.54) \\
\end{array}$ \\
\hline Profitability $_{i t}$ & & $\begin{array}{r}-0.345^{*} \\
(-1.93) \\
\end{array}$ & & $\begin{array}{c}-0.399^{* *} \\
(-2.37)\end{array}$ & & $\begin{array}{c}-0.476^{* * *} \\
(-3.13) \\
\end{array}$ \\
\hline Debt structure & & $\begin{array}{c}0.717^{* *} \\
(2.47) \\
\end{array}$ & & $\begin{array}{c}0.730^{* *} \\
(2.51)\end{array}$ & & $\begin{array}{c}0.365^{* *} \\
(2.58)\end{array}$ \\
\hline IFA & & $\begin{array}{l}0.396 \\
(1.33) \\
\end{array}$ & & $\begin{array}{l}0.479 \\
(1.44) \\
\end{array}$ & & $\begin{array}{r}-0.563^{*} \\
(-1.79) \\
\end{array}$ \\
\hline IP & & $\begin{array}{c}-0.779^{* * *} \\
(-3.80)\end{array}$ & & $\begin{array}{c}-0.812^{* * *} \\
(-3.08)\end{array}$ & & $\begin{array}{c}-1.041^{* * *} \\
(-4.23)\end{array}$ \\
\hline Industry & Yes & Yes & Yes & Yes & Yes & Yes \\
\hline Year & Yes & Yes & Yes & Yes & Yes & Yes \\
\hline$R$-sq: within & 0.516 & 0.612 & 0.590 & 0.627 & 0.482 & 0.519 \\
\hline Rho & 0.627 & 0.665 & 0.682 & 0.703 & 0.559 & 0.6384 \\
\hline $\operatorname{chi}^{2}$ & 178.66 & 226.17 & 351.06 & 211.84 & 179.84 & 211.02 \\
\hline Hausman & 0.0000 & 0.0000 & 0.0000 & 0.0000 & 0.0000 & 0.0000 \\
\hline
\end{tabular}

Note: $(1) * * *$ indicates statistical significance at the 0.01 level; $* *$ indicates statistical significance at the 0.05 level; $*$ indicates statistical significance at the 0.10 level. (2) Brackets for $t$ value. (3) $\mathrm{EFD}$ (3) is high level of external finance dependence, $\operatorname{EFD}(2)$ is intermediate level of external finance dependence, and $\mathrm{EFD}(1)$ is low level of external finance dependence.

4.4. Robustness Test of Panel Data Model. To test the reliability of regression results, this paper has carried out the following robustness test:

(1) Select the data between the sample data of $20 \%-80 \%$ to do regression analysis.

(2) To clarify external financing dependence, exclude firms whose debt is invariant or small changes.

(3) Divide the original sample data into two parts, 20032007 and 2008-2014. Regression results hint that the basic conclusions are equal. From Tables 10 and 11, the robustness tests of the results and the previous regression results are basically the same, indicating that the research conclusions have strong stability.

\section{Conclusion}

This paper consults researches of Antunes et al. and Uras to establish a model about capital misallocation and their influencing factors of integrated financing, capital operation, and investment performance and empirically test the microscopic influencing factors of capital misallocation under different external financing dependence and the critical influencing factors of capital misallocation taking Chinese listed companies, for instance, $[2,20]$. The empirical results are as follows:

(1) In descriptive statistics of different industries capital misallocation (KLDistort ${ }_{i t}$ ), we find that the mean, median, and quartile $50 \%$ of seven industries during 2003 to 2014 of capital misallocation are greater than 0 . It means that more than half of firms experience the circumstance of capital misallocation.

(2) Although Chinese listed companies are faced with financing constraints, capital market inefficiency, and other issues, most companies still depend on external financing. In 7096 observations, the proportion for the companies under high level of external financing dependence is about $49.8 \%$; the proportion for the companies under intermediate level of external financing dependence is about $16.148 \%$; the proportion for the companies under low level of external financing dependence is about $31.8 \%$.

(3) The main factors that affect capital misallocation of the listed companies are financial liquidity and financial pledgeability. The empirical analysis explains that, under different external financing dependence, the regression coefficient is diversified, but the regression coefficient is significantly negative.

(4) Innovation ability of the labor intensive firms is usually poor, which easily causes capital misallocation. In empirical analysis, the firms with high innovation abilities generally have stronger profitability, superior financial liquidity, and better financial pledgeability, thus reducing corporate capital misallocation. 
TABLE 10: Robustness test of panel data (model-3).

\begin{tabular}{|c|c|c|c|c|c|c|}
\hline \multirow{2}{*}{$\begin{array}{l}\text { Variables } \\
\text { liquidity }_{i t} \times \operatorname{EFD}(3)\end{array}$} & \multicolumn{6}{|c|}{$\tau_{s i}\left(1-\theta_{s i}\right)\left(1-\lambda_{s i}\right)$} \\
\hline & $\begin{array}{c}0.109^{* *} \\
(2.52) \\
\end{array}$ & $\begin{array}{c}0.0923^{* *} \\
(2.43) \\
\end{array}$ & & & & \\
\hline liquidity $_{i t} \times \operatorname{EFD}(2)$ & & & $\begin{array}{c}-0.0352^{* *} \\
(-2.47) \\
\end{array}$ & $\begin{array}{c}-0.0209^{* *} \\
(-2.44) \\
\end{array}$ & & \\
\hline liquidity $_{i t} \times \mathrm{EFD}(1)$ & & & & & $\begin{array}{c}-1.039^{* * *} \\
(-3.65)\end{array}$ & $\begin{array}{c}-0.867^{* * *} \\
(-3.34)\end{array}$ \\
\hline $\operatorname{Ln}(A)$ & & $\begin{array}{c}-0.557^{* * *} \\
(-4.03) \\
\end{array}$ & & $\begin{array}{c}-0.519^{* * *} \\
(-4.03)\end{array}$ & & $\begin{array}{c}-0.673^{* * *} \\
(-3.55)\end{array}$ \\
\hline Profitability $_{i t}$ & & $\begin{array}{c}-0.225^{* *} \\
(-2.43) \\
\end{array}$ & & $\begin{array}{c}-0.316^{* * *} \\
(-3.88)\end{array}$ & & $\begin{array}{c}-0.619^{* *} \\
(-2.47)\end{array}$ \\
\hline Debt structure & & $\begin{array}{c}0.432^{* * *} \\
(3.34)\end{array}$ & & $\begin{array}{c}0.597^{* *} \\
(2.46) \\
\end{array}$ & & $\begin{array}{c}0.576^{* *} \\
(2.52)\end{array}$ \\
\hline IFA & & $\begin{array}{c}0.225 \\
(0.783)\end{array}$ & & $\begin{array}{l}0.791 \\
(1.23)\end{array}$ & & $\begin{array}{c}1.023 \\
(0.968)\end{array}$ \\
\hline IP & & $\begin{array}{c}-0.877^{* * *} \\
(-3.54)\end{array}$ & & $\begin{array}{c}-1.21^{* * *} \\
(-3.74)\end{array}$ & & $\begin{array}{c}-1.049^{* * *} \\
(-4.21)\end{array}$ \\
\hline Industry & Yes & Yes & Yes & Yes & Yes & Yes \\
\hline Year & Yes & Yes & Yes & Yes & Yes & Yes \\
\hline $\begin{array}{l}R \text {-sq: within } \\
\text { Hausman }\end{array}$ & $\begin{array}{l}0.555 \\
0.0000\end{array}$ & $\begin{array}{c}0.617 \\
0.0000\end{array}$ & $\begin{array}{l}0.567 \\
0.0000\end{array}$ & $\begin{array}{l}0.655 \\
0.0000\end{array}$ & $\begin{array}{l}0.598 \\
0.0000\end{array}$ & $\begin{array}{l}0.703 \\
0.0000\end{array}$ \\
\hline
\end{tabular}

Note: $(1) * * *$ indicates statistical significance at the 0.01 level; $* *$ indicates statistical significance at the 0.05 level; $*$ indicates statistical significance at the 0.10 level. (2) Brackets for $t$ value. (3) $\mathrm{EFD}$ (3) is high level of external finance dependence, $\mathrm{EFD}(2)$ is intermediate level of external finance dependence, and $\mathrm{EFD}(1)$ is low level of external finance dependence.

TABLE 11: Robustness test of panel data (model-4).

\begin{tabular}{|c|c|c|c|c|c|c|}
\hline \multirow{2}{*}{$\begin{array}{l}\text { Variables } \\
\text { pledgeability }_{i t} \times \operatorname{EFD}(3)\end{array}$} & \multicolumn{6}{|c|}{$\tau_{s i}\left(1-\theta_{s i}\right)\left(1-\lambda_{s i}\right)$} \\
\hline & $\begin{array}{c}-0.041^{* *} \\
(-2.50)\end{array}$ & $\begin{array}{c}-0.037^{* *} \\
(-2.49)\end{array}$ & & & & \\
\hline pledgeability $_{i t} \times \operatorname{EFD}(2)$ & & & $\begin{array}{c}-0.212^{* * *} \\
(-4.13)\end{array}$ & $\begin{array}{c}-0.103^{* * *} \\
(-4.01)\end{array}$ & & \\
\hline pledgeability $_{i t} \times \operatorname{EFD}(1)$ & & & & & $\begin{array}{c}-0.597^{* * *} \\
(-3.79)\end{array}$ & $\begin{array}{c}-0.556^{* * *} \\
(-3.39)\end{array}$ \\
\hline $\operatorname{Ln}(A)$ & & $\begin{array}{c}-0.563^{* * *} \\
(-3.28)\end{array}$ & & $\begin{array}{c}-0.703^{* * *} \\
(-3.45)\end{array}$ & & $\begin{array}{c}-0.903^{* * *} \\
(-4.22)\end{array}$ \\
\hline Profitability $_{i t}$ & & $\begin{array}{c}-0.419^{*} \\
(-1.84)\end{array}$ & & $\begin{array}{r}-0.417^{* *} \\
(-2.44)\end{array}$ & & $\begin{array}{c}-0.391^{* * *} \\
(-3.64)\end{array}$ \\
\hline Debt structure & & $\begin{array}{c}0.635^{* *} \\
(2.51)\end{array}$ & & $\begin{array}{c}0.663^{* *} \\
(2.47)\end{array}$ & & $\begin{array}{c}0.441^{*} \\
(1.88)\end{array}$ \\
\hline IFA & & $\begin{array}{l}0.773 \\
(0.97) \\
\end{array}$ & & $\begin{array}{l}0.559 \\
(1.35) \\
\end{array}$ & & $\begin{array}{r}0.947 \\
(1.13) \\
\end{array}$ \\
\hline IP & & $\begin{array}{c}-0.904^{* * *} \\
(-4.96)\end{array}$ & & $\begin{array}{c}-0.724^{* *} \\
(-2.48)\end{array}$ & & $\begin{array}{c}-0.891^{* * *} \\
(-3.99)\end{array}$ \\
\hline Industry & Yes & Yes & Yes & Yes & Yes & Yes \\
\hline Year & Yes & Yes & Yes & Yes & Yes & Yes \\
\hline $\begin{array}{l}R \text {-sq: within } \\
\text { Hausman }\end{array}$ & $\begin{array}{c}0.571 \\
0.0000\end{array}$ & $\begin{array}{c}0.639 \\
0.0000\end{array}$ & $\begin{array}{c}0.607 \\
0.0000\end{array}$ & $\begin{array}{c}0.649 \\
0.0000\end{array}$ & $\begin{array}{c}0.530 \\
0.0000\end{array}$ & $\begin{array}{c}0.677 \\
0.0000\end{array}$ \\
\hline
\end{tabular}

Note: $(1) * * *$ indicates statistical significance at the 0.01 level; $* *$ indicates statistical significance at the 0.05 level; $*$ indicates statistical significance at the 0.10 level. (2) Brackets for $t$ value. (3) $\mathrm{EFD}(3)$ is high level of external finance dependence, $\operatorname{EFD}(2)$ is intermediate level of external finance dependence, and $\mathrm{EFD}(1)$ is low level of external finance dependence. 
(5) A lot of domestic researches point out that the Chinese listed companies with large-scale assets and strong profitability easily obtain bank loans and equity financing, while violating the principle of assets matching.

\section{Competing Interests}

All the authors of this paper declare that there are no competing interests in connection with the work submitted.

\section{Acknowledgments}

This work is funded by Zhejiang Social Sciences Planning Project (no. 14NDJC099YB), the National Statistical Scientific Research Projects (no. 2014078), the National Social Science Fund Projects in China (stage results) (no. 15FJY009), the National Natural Science Foundation of China (nos. 71171176 and 71471161), and the Key Program of the National Natural Science Foundation of China (no. 71631005).

\section{References}

[1] D. Restuccia and R. Rogerson, "Policy distortions and aggregate productivity with heterogeneous establishments," Review of Economic Dynamics, vol. 11, no. 4, pp. 707-720, 2008.

[2] B. R. Uras, "Corporate financial structure, misallocation and total factor productivity," Journal of Banking \& Finance, vol. 39, no. 1, pp. 177-191, 2014.

[3] C.-T. Hsieh and P. J. Klenow, "Misallocation and manufacturing TFP in China and India," Quarterly Journal of Economics, vol. 124, no. 4, pp. 1403-1448, 2009.

[4] P. Yan, "A investigation into capital misallocation," China Economic Quarterly, vol. 11, no. 2, pp. 489-519, 2012.

[5] X. S. Qian, "A study on efficiency of firm's internal capital allocations-a general equilibrium approach based on financial discrimination and insider control," Accounting Research, no. 2, pp. 43-50, 2013.

[6] V. Midrigan and D. Y. Xu, "Finance and misallocation: evidence from plant-level data," American Economic Review, vol. 104, no. 2, pp. 422-458, 2014.

[7] Z. Song, K. Storesletten, and F. Zilibotti, "Growing like China," American Economic Review, vol. 101, no. 1, pp. 196-233, 2011.

[8] O. Z. Li, X. J. Su, and Z. H. Yang, "State control, access to capital and firm performance," China Journal of Accounting Research, vol. 5, no. 2, pp. 101-125, 2012.

[9] Y. W. Chen and W. M. Hu, "Distortions, misallocation and losses: theory and application," China Economic Quarterly, vol. 10, no. 4, pp. 1401-1422, 2011.

[10] Q. E. Gai, X. Zhu, M. W. Cheng, and Q. H. Shi, "Factor market distortion, monopoly power and total factor productivity," Economic Research Journal, vol. 50, no. 5, pp. 61-75, 2015.

[11] Q. L. Mao, "Factor market distortion and the productivity of industrial firms in China: an analysis based on the liberalization of trade," Journal of Financial Research, no. 2, pp. 157-169, 2013.

[12] M. H. Zhan, X. J. Wang, and C. W. Ying, "Interest rate regulation behavior distortion of banks' credit allocation and the financial restriction of Chinese Listed Companies," China Economic Quarterly, vol. 12, no. 4, pp. 1255-1276, 2013.
[13] L. H. Wang and L. Yuan, "Was capital misallocation an important factor for loss in total factor productivity?" Statistical Research, vol. 31, no. 8, pp. 11-18, 2014.

[14] Z. X. Han and T. T. Zhou, "Product market competition, financing constraints and cash holdings: an empirical study based on enlisted companies in China's manufacture industry," Nankai Business Review, vol. 14, no. 4, pp. 149-160, 2011.

[15] Y. Duan and Y. Guo, "Political relation, monetary policy and debt structure," Nankai Business Review, vol. 15, no. 5, pp. 8494, 2012.

[16] M. Faulkender and R. Wang, "Corporate financial policy and the value of cash," The Journal of Finance, vol. 61, no. 4, pp. 19571990, 2006.

[17] Q. He and H. P. Li, "Financial constraints, cash holding, and firm's investment timing decision," Nankai Economic Studies, no. 3, pp. 67-82, 2013.

[18] H. Almeida, M. Campello, and M. S. Weisbach, "The cash flow sensitivity of cash," Journal of Finance, vol. 59, no. 4, pp. 17771804, 2004.

[19] S. N. Kaplan and L. G. Zingales, "Do investment-cash flow sensitivities provide useful measures of financing constraints?" The Quarterly Journal of Economics, vol. 112, no. 1, pp. 169-215, 1997.

[20] A. Antunes, T. Cavalcanti, and A. Villamil, "The effect of financial repression and enforcement on entrepreneurship and economic development," Journal of Monetary Economics, vol. 55, no. 2, pp. 278-297, 2008.

[21] K. Matsuyama, "Credit traps and credit cycles," American Economic Review, vol. 97, no. 1, pp. 503-516, 2007.

[22] A. Vercelli, "A perspective on minsky moments: revisiting the core of the financial instability hypothesis," Review of Political Economy, vol. 23, no. 1, pp. 49-67, 2011.

[23] S. Sordi and A. Vercelli, "Heterogeneous expectations and strong uncertainty in a Minskyian model of financial fluctuations," Journal of Economic Behavior and Organization, vol. 83, no. 3, pp. 544-557, 2012.

[24] R. G. Rajan and L. Zingales, "Financial dependence and growth," The American Economic Review, vol. 88, no. 3, pp. 559586, 1998.

[25] M. Vassalou and K. Apedjinou, "Corporate innovation, price momentum, and equity returns," Working Paper, 2004.

[26] A. C. Eberhart, W. F. Maxwell, and A. R. Siddique, "An examination of long-term abnormal stock returns and operating performance following R\&D increases," The Journal of Finance, vol. 59, no. 2, pp. 623-650, 2004.

[27] S. Sordi and A. Vercelli, "Heterogeneous expectations and strong uncertainty in a Minskyian model of financial fluctuations," Journal of Economic Behavior \& Organization, vol. 83, no. 3, pp. 544-557, 2012. 


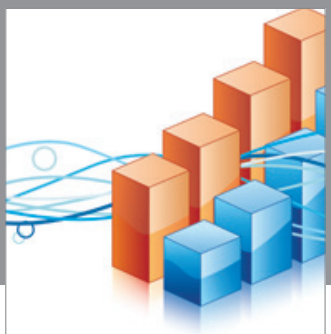

Advances in

Operations Research

vatem alat4

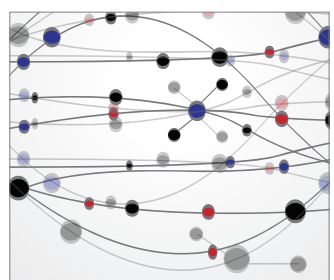

\section{The Scientific} World Journal
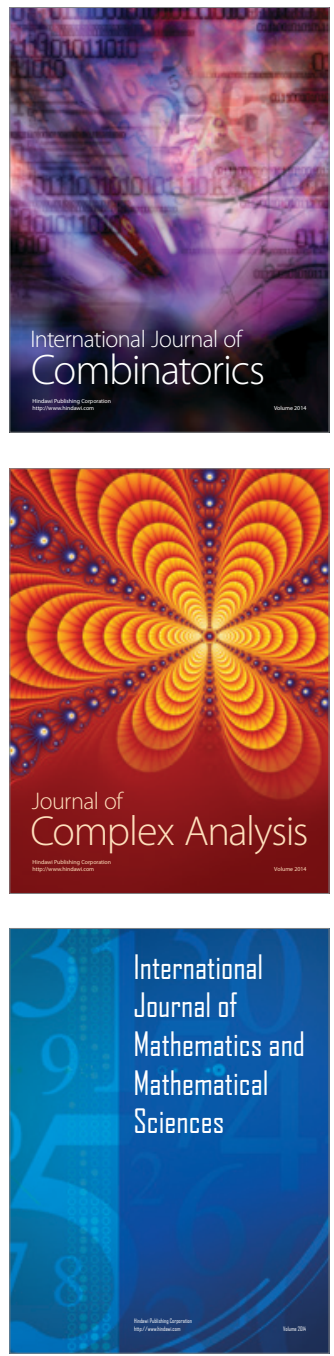
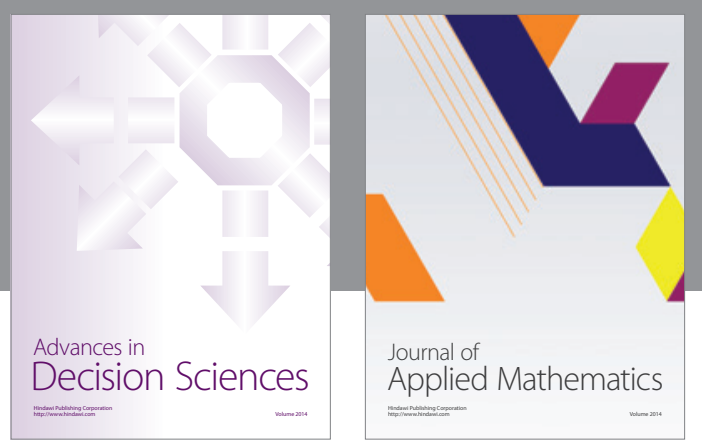

Algebra

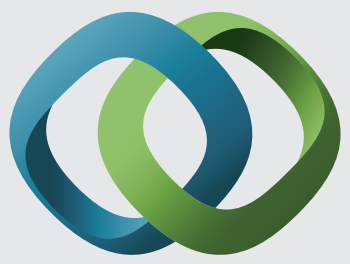

\section{Hindawi}

Submit your manuscripts at

http://www.hindawi.com
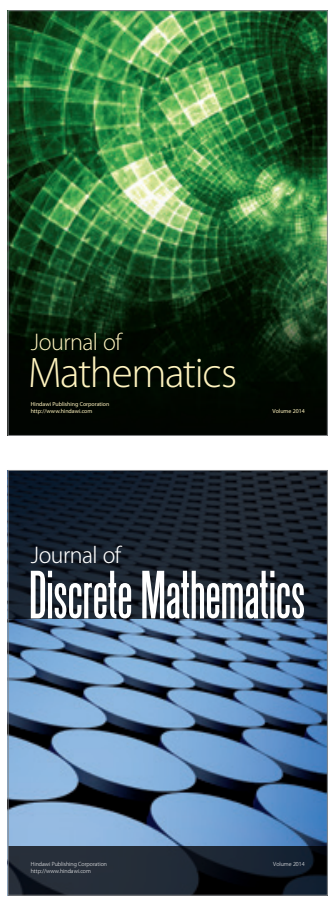

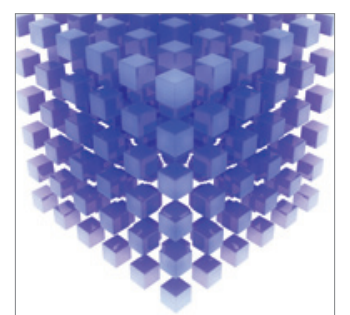

Mathematical Problems in Engineering
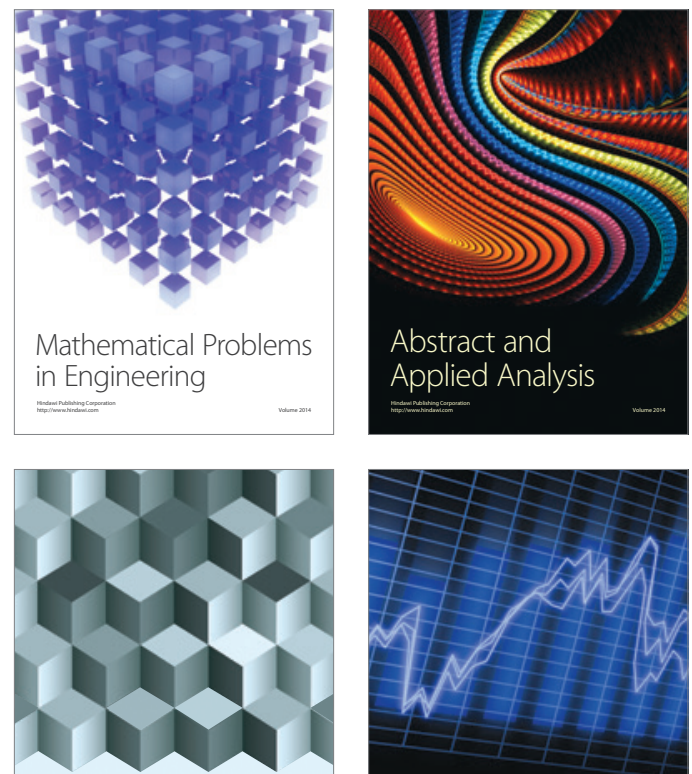

Journal of

Function Spaces

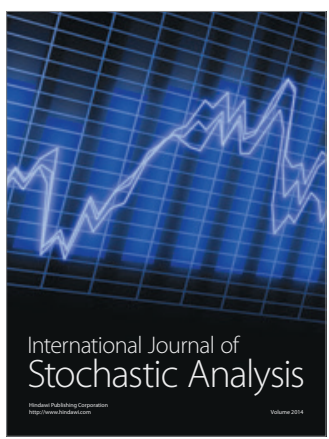

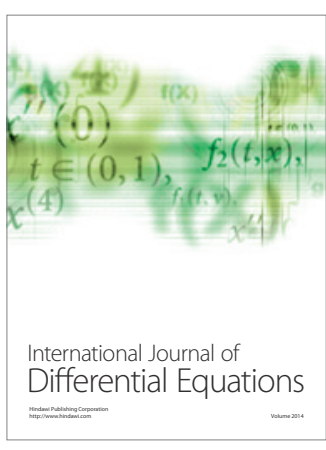
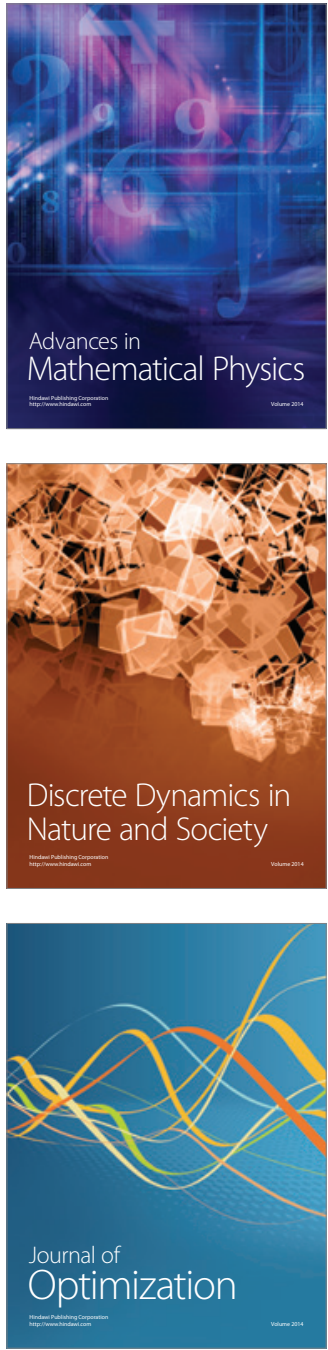